\title{
Remembrance, Public Narratives, and Obstacles to Justice in the Western Balkans
}

\author{
JELENA SUBOTIC ${ }^{1}$ \\ Georgia State University, USA
}

\begin{abstract}
Twenty years since the onset of the traumatic wars of Yugoslav secession, the countries of the Western Balkans continue to nurture narratives of the past that are mutually exclusive, contradictory, and irreconcilable. The troubling ways in which states in the region remember their pasts provide continuing obstacles in the search for acknowledgment and justice. In this essay, I develop an argument for understanding the relationship between justice and remembrance of the past. To illustrate this relationship, I explore ways in which education and memorialization projects contribute to justice efforts. I critically analyze a few ongoing education and memory projects in the region, and then present alternative ideas on mechanisms of public memory that would be more conducive to building the foundational blocks of justice based on trust, respect, and dignity.
\end{abstract}

\section{Introduction}

On his first day in office in June 2012, the newly elected Serbian president Tomislav Nikolić said that no genocide took place in Srebrenica, and that, in any case, genocide was "difficult to prove in court" (B92, 2012). Bosnian Presidency Chairman Bakir Izetbegović responded immediately that Nikolić's statement was "untrue and offensive for Bosniacs, especially for the survivors of Srebrenica genocide . . . Serbian leaders and Serbian people need to face the truth about crimes committed in Bosnia-Herzegovina in order to improve state relations and enable that the future in the region is better than its past" (B92, 2012).

But this was not Nikolić's first foray into historical justice debates. Just before the second round of presidential elections, he declared that a "greater Serbia was [his] unrealized dream" and that "Vukovar was a Serbian town to which Croats should not return" (Pavelić, 2012a). While he quickly backtracked and denied this claim given in an interview to a German 
newspaper, his original statement caused an uproar in Croatia and was the subject of much passionate debate on Croatian TV in days to come. The Croatian president, Ivo Josipović, gave a stern response: "Croatia knew how to defend its sovereignty [in the past] ... it will know how to defend it today" (Pavelić, 2012a).

Twenty years after the start of the Yugoslav wars, the countries of the region are still stuck in public narratives of the past that are mutually exclusive, contradictory, and irreconcilable. I suggest that there is a direct link between ways in which different states remember their pasts and efforts to bring justice for past wrongs in the Western Balkans. Instead of being productive instruments of transitional justice, official remembrance efforts in the region in the areas of history education and national memorialization have been largely used to entrench further mutually incompatible versions of the past and contribute to a renewed cycle of mistrust, untruth, and injustice. I suggest that memory projects need to be redesigned to include a much broader regional focus which would compel states in the region to confront their pasts directly, and not dwell on their own victimization in isolation. Regional commissions of inquiry, comprehensive education reform, and multi-state memorialization projects should, therefore, not be thought of as secondary initiatives, but as critical steps in pursuit of regional justice based on trust, respect, and dignity. However, profound political change must take place first.

The essay is structured as follows. First, I present a brief argument about the relationship between justice and remembrance of the past. Then I explore ways in which education and memorialization projects contribute to justice efforts. Next, I illustrate the state of contemporary public debates about the past in Serbia, Croatia and Bosnia with a focus on education and memorialization policies. I conclude by proposing mechanisms of public memory that would be more conducive to long-term reconciliation and regional justice, understood here as the basic tenets of transitional justice: reckoning with past wrongs, acknowledging victims' suffering, and repairing broken societies.

\section{Justice and Remembrance of the Past}

Transitional justice, which is a set of mechanisms aimed at addressing legacies of violence, has greatly expanded and deepened over the past twenty years as a field of inquiry. Early efforts at systematically addressing crimes of the past focused mostly on trials of perpetrators and on truth commissions and they were dominated by legal models and solutions (Teitel, 2003). Transitional justice as a field has since been broadened to include a much wider range of mechanisms, ideas, and policies (Bell, 2009). The principal assumption of transitional justice, however, remains that finding out the truth about past wrongs, identifying the perpetrators, and punishing them appropriately, achieves justice by ending impunity (Mendeloff, 2004). 
The claim that finding out the truth and that remembering the past accomplishes justice is an ambitious one and can be broken down to a few analytical steps. First, the creation of a reliable record of past events offers a platform for victims to tell their stories and restore the dignity of the victim, while also integrating the perpetrator back into society, which is the goal of restorative justice. Second, exposing the truth and public remembrance can result in proposing legal or political remedies to avoid future violence, and also in determining individual responsibility and punishment of perpetrators (a form of retributive justice). Richard Goldstone, the first prosecutor of the ICTY, even argued that "the public and official exposure of the truth is itself a form of justice" (Goldstone, 1995, p. 491). Finally, public remembrance can repair the injury suffered by victims through restitution, reparations, or apologies, which is a form of reparative justice (Minow, 1998). At the individual level, remembrance is thought to bring individual victims justice by acknowledging their suffering, hearing their stories, and helping to heal the trauma that results from violence. Remembrance can also lead to justice by preventing revenge killing and instead placing retribution for atrocity within the framework of individual criminal accountability, and avoiding collective guilt. When justice is delivered through criminal prosecutions of individual perpetrators, it can break the cycle of violence by ending impunity.

At the public level, states can institutionalize a certain practice of remembrance through education, such as in history textbooks, but also through public commemoration practices such as monuments, museums, street names, memory sites, and national holidays. Public remembrance that produces a new, authoritative historical record of past violence can help create a new, shared history of groups in conflict, which then opens up the possibility for group reconciliation and more peaceful coexistence in the future. Public education is critical for this effort. Creating a credible account of past violence can provide an opportunity for a traumatized society to learn from its criminal past and prevent similar atrocities from happening in the future (Hayner, 1994).

Germany's waves of postwar education reform and its impact on understanding the legacies of violence and the changing political culture of modern Germany is very well documented, especially in contrast to the lackluster efforts of education reform in Japan (Buruma, 1994; Hein \& Selden, 2000). More recently, the truth commission in Chile has made the connection between education and human rights promotion quite explicit, in recommending that human rights be integrated into all taught subjects so that students can use this knowledge as they learn to understand and deal with contemporary political problems (United States Institute of Peace, 1993). In Guatemala, the Truth Commission Report invigorated the discussion about the violent past and motivated teachers and schools to incorporate the report into their official curricula (Oglesby, 2007). In Argentina, every 24 March (anniversary of the 1976 coup) all schools are required to teach special classes on the meaning of human rights and the dictatorship. There are also many organized school trips to former concentration camps like Escuela de 
Mecánica de la Armada (ESMA) in Buenos Aires or La Perla in Cordoba. Post-conflict education, therefore, has the potential to "demystify the past" and inculcate the public culture of human rights (Sarkin, 1999) or, even broadly, the culture of peace (Oglesby, 2007). Public education about the violent past is especially important for "perpetrator states," where society has yet to undergo a profound repudiation of the criminal past (Dimitrijević, 2008).

Changing entrenched narratives is a difficult task. Uncontested public memories of past conflicts become salient because they are assimilated into public discourse and become very difficult to challenge, reproducing themselves over time, and taking on a life of their own (McGrattan, 2010). These public beliefs then become integrated into social institutions that act as "collective memory archives" (Aguilar, 2002) for different political actors to draw upon. Public education after conflict is, therefore, important in order "to reduce the number of lies that can be circulated unchallenged in the public discourse" (Ignatieff, 1998, p. 173). Further, schools themselves are often spaces where profound systemic injustices are reproduced, through inclusion or exclusion of different groups, classes, and types of students and through teaching of stories of exclusion, separation, and isolation (Cole, 2007). Schools are, therefore, unique locations of a wider societal repair (Weinstein, Freedman, \& Hughson, 2007).

History education in particular is critical to the success of a broader transitional justice project in post-conflict societies. How citizens understand history is crucial to a society's ability to deal with the difficult past and build a more just future (Cole, 2007). History education is an integral part of the larger transitional justice effort as it can deepen and personalize official acknowledgment of the harm done and suggest ways to embark on social repair.

Teaching of the past, however, is fraught with analytical, ethical, and interpretive minefields. History education, especially at the pre-college level, has traditionally been the most conservative area of education, focusing much more freely on the distant than on the recent past, and therefore the area of education most scrutinized by the state (Cole, 2007). Further, history will and should always be contested, and the idea of multi-perspectivism is a growing trend in historical pedagogy. While this means that multiple interpretations of past events may be welcomed, it also means that a new reinterpretation of the past can be used for a renewed conflict in the future (Cole, 2007).

The next section evaluates a few recent efforts at state remembrance of the past in the Western Balkans as preconditions for the pursuit of post-conflict justice in the region. The analysis of remembrance, broadly understood, is especially needed in the scholarship on the Balkans, since most of the transitional justice literature on the region has focused almost exclusively on the retributive justice efforts, namely trials for perpetrators of war crimes before domestic courts and the International Criminal Tribunal for the former Yugoslavia/ICTY (Nettelfield, 2010a; Orentlicher, 2008, 2010; Subotić, 2009). The emphasis on retributive justice in Western Balkans scholarship 
has followed the same emphasis in international policymaking, as most international efforts and incentives were designed to improve investigations and prosecutions of individual perpetrators. This focus on retribution has then effectively equated the larger field of transitional justice with just its one possible dimension, punishment, and has de-emphasized many other available mechanisms that are designed to work on societal reparation or restoration. That is why this essay focuses deliberately on two other measurements of transitional justice: history education and national memorialization. My research shows that, instead of being used as instruments of transitional justice in the region, official remembrance projects in public education and commemoration have been used to entrench mutually incompatible versions of the past and contribute to a renewed cycle of mistrust, untruth, and injustice.

\section{Remembering the Past in the Western Balkans}

There are few better ways to reconstruct state remembrance of its past than analyzing history textbooks. As Mendeloff has argued, history textbooks embody lowest common denominator history as "a distilled version of popular history and historical memory that appeals to the widest possible audience" (Mendeloff, 2008, p. 37). History textbooks are important barometers of dominant state remembrance because they are explicitly designed to inculcate particular views of the past into future generations. But memories of the past and the understanding and interpretation of history are always rewritten for the purposes of the political present (Stojanović, 2011). The problem with history education in the Western Balkans, then, is that this region's histories are multiple, contradictory, and mutually exclusive. Far from being a tool for social cohesion and healing, they continue to be instruments of political othering, alienation, and further injustice.

\section{Serbia}

After President Slobodan Milošević was removed from power in 2000, new, revised, history textbooks were published in Serbia. ${ }^{2}$ While the language was improved and some of the more overt hate speech from earlier textbooks toned down, the fundamental view about Serbia's past, especially as it relates to the breakup of the former Yugoslavia, remained mostly intact. The Serbian state continues to be represented as a victim, and Yugoslavia as a country destroyed by separatists in Slovenia, Croatia, and Bosnia, who worked against the interests of the Serbian nation (Stojanović, 2011). Serbian regional territorial aspirations, therefore, are interpreted not just as defensive, but also as preventive, to stop the inevitable crimes against the Serbian people. This political concern is what has guided the new Serbian President Nikolić to warn of an "impending genocide against Serbs in Kosovo" (The Guardian, July 29, 2012).

This state effort at keeping silent about the Serbian criminal past has been largely successful. Surveys consistently show that the public mostly refuses 
to believe that Serbs had committed war crimes, and Serbs blamed other nations and ethnic groups for starting the wars (Ramet, 2007). In a recent large survey of popular knowledge about Serbian history, only $34 \%$ of the respondents correctly identified the victims of Srebrenica as Bosniacs, and only $10 \%$ reported that Croats, not Serbs, were killed in a mass atrocity in Ovčara, outside Vukovar, Croatia in 1991 (Manojlović Pintar, 2010, p. 97). It is difficult to ascertain whether this is simply ignorance of past events, or a more profound strategy of a "conspiracy of shame" (Ćurgus Kazimir, 2005), where traumatic events for which we are responsible become a deeply buried family secret, never to be discussed aloud.

While at the level of retributive justice, the transfer of the last remaining war crimes fugitives to The Hague, and the ongoing trials before the Serbian War Crimes Chamber are very significant and demonstrate improved commitment to the rule of law, in terms of reparative justice and state apologies, Serbia has made a few contradictory moves. For example, the Serbian Parliament in March 2010 adopted the domestically very controversial "Declaration on Srebrenica," which acknowledged the massacre at Srebrenica while never mentioning the term "genocide." This rhetorical strategy is an example of "interpretive denial," where crimes of the past are not denied as outright lies, but are interpreted in a manner that gives past events a very different meaning (Cohen, 2001). Another example of interpretive denial of the Srebrenica genocide is the shift in focus of denial in the Serbian intellectual discourse. While the events at Srebrenica used to be flatly denied, they are now begrudgingly accepted as valid, but the number of victims is now dramatically lowered in most of the media reports (Helsinki Committee for Human Rights in Serbia, 2011). The Declaration on Srebrenica, therefore, was a missed opportunity for the Serbian government to make a clean admission and to deconstruct the public remembrance of Serbia's past. Instead, it served to entrench further the dominant memory of the past in Serbia and to foreclose on opportunities for engagement and dialogue with victims of Serbia's war effort.

What Serbia remembers most from the wars of the 1990s is, of course, its own victimization, the NATO intervention in 1999. The NATO war only further solidified Serbian feeling of being a victim and suffering a great sense of injustice at the hands of great powers. In fact, a succession of Serbian governments post 1999, even after Milošević's ousting in 2000, consciously decided to promote the memory of Serbians' sense of martyrdom during the NATO air war "as if it were the central motive of the wars in the 1990s" (David, 2012).

The evidence of this story is clear even with a cursory look at the official Serbian national calendar, "The State Program for Commemorating the Anniversaries of Historic Events of the Serbian Liberation Wars," which was adopted after much discussion and delay in March 2009. According to this official government document, the wars of Yugoslav succession in the 1990s either never happened, or did not involve Serbia as a major participant. Various historical events representing Serbian victimhood or injustice suffered are, 
however, present in seven commemorative national holiday days (David, 2012). ${ }^{3}$ Similarly, the Serbian state embarked on a comprehensive project of renaming city streets, replacing all names associated with communist or antifascist heroes which were numerous since 1945, with heroes or heroic events more broadly associated with Serbian tradition, anticommunism, nationalism, and especially the Orthodox Church (Govedarica, 2012). ${ }^{4}$

What the state wants citizens to remember, therefore, are instances of loss, injustice, and pain inflicted on heroic Serbs of the past. What it wants these citizens to forget are any memories of the Serbian state and its citizens inflicting pain or misery on others, or even acknowledge the suffering beyond its borders. Even what is considered the historical incidence of suffering par excellence, the Holocaust, is first memorialized as a crime against Serbs, and only then as a crime against Jews and others (Byford, 2007). The understanding of Serbia's past, therefore, continues to shape its future. Serbia's remembrance is not inclusive of the memory of others. It is exclusionary, isolating, and far from ready for the reconciliatory narrative reconstruction necessary for continuing justice efforts.

\section{Croatia}

The central tenet of Croatian remembrance of the past as derived from its history education is that "Croats never fought aggressive, but only defensive wars" (Agičić \& Najbar-Agičić, 2007, p. 204). This view is also reflected in the historical interpretation of Croatia's Homeland War of the 1990s, which is taught exclusively as the consequence of Serbian aggression and terrorism, without any broader context of Yugoslav succession. Most textbooks dedicate considerable space to discussing Serbian crimes against Croatian civilians, but only one textbook even mentions, in passing, that thousands of Serbs were forced to leave Croatia in 1995 during the ethnic cleansing campaign that accompanied Operation Storm (Agičić \& Najbar-Agičić, 2007).

While the textbook market was liberalized in 2000 and opened to competition since then (a process still not undertaken in Serbia), many of the books in circulation still use extreme nationalist language and concepts, not much reformed since the early 1990s. The fascist Independent State of Croatia is often glorified, and crimes of the Ustasha ${ }^{5}$ regime marginalized or avoided (Pavasović Trošt, 2012). In fact, most of the Croatian textbooks currently in use "create in students the impression that Croatia has always been inhabited exclusively by Croats, while other ethnic groups appear as malicious newcomers and instigators of conflicts and problems" (Agičić \& Najbar-Agičić, 2007, p. 212).

In 2005, a controversy erupted in Croatia regarding a new Contemporary History Textbook Supplement, a textbook written by a younger generation of Croatian historians, which included a critical analysis of Croatian efforts in the 1990s, as well as a statement that Croatian forces had committed war crimes against Serb civilians. The Croatian Education Ministry refused to approve this supplement, and a number of distinguished Croatian historians wrote open letters accusing the supplement authors of lack of patriotism. 
The authors were criticized for not using the term "liberation" when discussing Operation Storm, for overemphasizing the suffering of Serbs, and for painting Operation Storm in a "negative light" (Agičić, 2011, pp. 361362). The critics also offered this bold statement: "history textbooks must take into consideration not only scientific and pedagogic standards, but also national and state criteria" (Agičić, 2011, p. 362). It is hard to find more direct evidence of the role history education plays in nation-building projects than this attitude of the Croatian intellectual elite.

On numerous occasions, the Croatian Parliament had legislated the memory of the war in Croatia and offered laws on how this event is to be commemorated, understood, and interpreted. Various Members of Parliament have put forward proposals for how to memorialize the war appropriately. In 2000, the Parliament adopted the "Declaration on the Homeland War," which compels "all officials and official organs of the Republic of Croatia to protect the fundamental values and dignity of the Homeland War" (Croatian Parliament, 2000), which in practice meant to discourage any discussion of Croatian war crimes. The Declaration explicitly states that Croatia "led a just and legitimate, defensive and liberating, and not aggressive nor occupying war against any one; instead it defended its territory from Greater Serbian aggression within internationally recognized borders" (Croatian Parliament, 2000). In 2006, the Croatian Parliament adopted the "Declaration on Operation Storm," which requests from "the Croatian Parliament, Croatian scientific community, Croatian institutions of science and education, as well as media, to over time turn Operation Storm into a battle that will become part of Croatia's 'useful past' for its future generations" (Croatian Parliament, 2006).

Croatia's state remembrance is evident in many other official memorialization practices. For example, Croatian government continues to finance commemorations to Croatian fascist Ustasha troops executed by communists in 1945 at Bleiburg (Kolsto, 2010). The Croatian state also implicitly downplays the number of genocide victims killed during the World War II fascist-era Croatia, most notably in the way in which the contemporary exhibit is laid out and interpreted at Jasenovac concentration camp memorial site (Pavasović Trošt, 2012; Pavlaković, 2008). ${ }^{6}$ Ironically, however, the former Croatian Prime Minister Ivo Sanader used the occasion of the Holocaust commemoration at Jasenovac in 2005 to make a remarkable equivalency claim between Croatian suffering during the Homeland War of the 1990s and the Holocaust: "We should not forget the aggression that Croatia endured because we too were victims of a terrible madness of Nazism and fascism, and we, Croatian citizens, Croats, know the best what it is like to suffer from aggression" (Banjeglav, 2012, p. 115). Seemingly lost on the Prime Minister is the fact that the memorial site itself is a commemoration of the indigenous Croatian fascist movement and not of Croatian victimization.

The choice of Croatia's national holidays also demonstrates the official state strategy of what is to be remembered and how. There are three new national holidays that commemorate key moments in Croatia's so-called 
homeland war: the Day of Victory and Homeland Thanksgiving (August 5, the date of the resolution of Operation Storm), Independence Day (October 8, the date Croatian Parliament declared Croatia's independence from the former Yugoslavia), and the fall of Vukovar (November 18). The August 5 celebration is especially significant in this context because since 2004, the Croatian government made it a practice for the entire Croatian political leadership (the President, Prime Minister and Speaker of the Parliament) to attend the memorial in Knin. The site of Knin is additionally symbolic since it was historically the seat of the former Croatian kingdom, and during the 1990s war the headquarters of the Croatian Serb rebellion (Pavlaković, 2010). It is during one of these commemorations, in 2006, that Prime Minister Sanader proclaimed that "'Storm' was not a crime; 'Storm' defeated the crime" (Jutarnji list, August 6, 2006). In 2010, a youth organization erected a small plaque/monument for the Serbian victims of Operation Storm outside of Knin. The plaque was placed by the side of the road leading north of the city, to symbolize the thousands of Serb refugees who fled their homes during and after the military operation. Within 24 hours, however, the plaque was removed by the Knin city authorities, who claimed that the plaque did not have the necessary permits, even though it was built with Croatian government support which was later denied (Banjeglav, 2012). The public remembrance of the city of Knin, therefore, is an example of the mutually exclusive power of memory: for Croatia, it is the site of triumph and independent statehood. For Serbia, it is the site of its failed Croatian project, and of the memory of Serbian exodus and loss.

More broadly, the way in which the recent, and even distant past, is remembered makes state narratives in Croatia and Serbia incompatible. Croatia remembers Operation Storm as the pinnacle of its fight for independence, an event that made the contemporary Croatian state possible. Serbia remembers Operation Storm as a site of Serbian defeat, and a site of ethnic cleansing of Serb civilians. For the Croatian narrative, this criminalization of Operation Storm is inconceivable, because it criminalizes the Croatian state itself. The two narratives are speaking past each other; there is no discursive space in either of them for inclusion of an alternative, conciliatory, story. These are stories of exclusion and separation; these are not stories that build a sense of community. The fact that in November 2012 the ICTY acquitted two Croatian generals from any responsibility for the war crimes that followed Operation Storm (International Criminal Tribunal for the Former Yugoslavia, 2012) has given further fuel to these narratives: in Croatia, of the purity and nobility of Operation Storm; in Serbia of another historical injustice against the Serbian people.

\section{Bosnia}

In Bosnia, even more so than in Serbia or Croatia, history has developed an ethnicity of its own. In the aftermath of the Dayton Accords and the administrative partition of Bosnia, education policy has been decentralized and put in the hands of local authorities (Jones, 2012). Like everything else 
in postwar Bosnia, education has come to represent ethnic politics of the majority population in a particular region. Attempts at centralizing education platforms or unifying efforts in this sphere have failed, a consequence of the Dayton political reality that locked ethnic politics in their place and gave two major Bosnian political entities trappings of statehood (McMahon \& Western, 2009; Perry, 2013).

What this means for the practice of history education is that not only are history narratives in Bosnia incompatible with those in Serbia and Croatia, but the three versions of the Bosnian past (Serbian, Croatian, and Bosniac) are incompatible within Bosnia itself. Bosnian students still use three very different sets of history textbooks: Historija for the Bosniac students printed in Sarajevo, Povijest for the Croatian students and imported from Croatia, and Istorija for the Serbian students published in Belgrade, with an additional Supplement written specifically for the Bosnian Serb education market (Torsti, 2013). The absurdity of this ethnicization of education results in the fact that only the Bosniac-language textbook, Historija, reflects the history of Bosnia in any systematic way, while the Croatian and Serbian versions refer to Croatia and Serbia, respectively, as ethnic homelands and mostly build on Croatian and Serbian historical narratives, different from, and largely opposed to, the narrative of the new Bosnian state. For example, Historija narrates the war of the 1990s through stories of Bosniac suffering, the unfair nature of war events, and responsibility of outside powers for the conflict. It explains the cause of the war as aggression on the independent Bosnian state. The Serbian textbook, however, interprets the war as the result of Slovenian, Croatian, and Bosnian separatism that broke the former Yugoslavia apart, while the Croatian textbook does not specify the cause of the war at all (Torsti, 2003).

Over the past 15 years, there have been multiple efforts, mostly driven by international actors, to reform Bosnian education curricula, especially in History and the Social Sciences. As part of the conditions for Bosnian admission to the Council of Europe in 1999, Bosnia was required to eliminate potentially offensive material from their textbooks. However, since they ran out of time to publish new textbooks, the education authorities instead agreed to blank and annotate the existing textbooks in sections deemed controversial. This rather absurd solution then led to equally absurd outcomes, such as student efforts to read through the blanked out text, even further elevating the importance of these "forbidden texts" (Torsti, 2013).

Almost two decades since the end of the war, these problematic textbooks are still in circulation in Bosnia. The 2007 Open Society Institute review found that Bosnian history textbooks are "dividing and spreading hatred toward other national groups by relying on idealized auto-stereotypes of one's own groups and negative hetero-stereotypes of the other national groups," with Croatian and Serbian books being the biggest offenders (quoted in Torsti, 2013).

The problem with Bosnian education, however, is not only textbook content, but also the structural issues of education segregation. It follows 
larger patterns of ethnic segregation in postwar Bosnia, and manifests itself in various models of physical segregation: demographic segregation that is the result of wartime ethnic cleansing and population displacement, the "separate but equal" model of "two schools under one roof," school busing policies that reinforce ethnic segregation by sending children to distant schools in order to educate ethnic groups "with their own kind," or mixed schools where minority students study "sensitive" national subjects (history, geography, language, religion) separately from everyone else (Perry, 2013). Integral to this effort of ethnicizing history is the obsession with language distinctions. Bosnian Serbs have come to use the Cyrillic alphabet exclusively to differentiate their written language from its Bosniac and Croatian counterparts. However, the Bosniac and Croatian linguists have gone out of their way to construct increasingly separate language variants: the Bosniac version includes ever more Turkisms; the Croatian version brings back old-Croatian elements. This is all in the effort to make the Serbo-Croatian language (historically the principal unifier of the region) increasingly a marker of divergence and ethnic difference. These education strategies have created a new form of school geography, which is built on and further reproduces ethnic symmetry and division (Hromadžić, 2008).

The way in which the story of Bosnia is told in history education, therefore, is the story that serves further ethnic division and politicization of the past in the country. The Bosnian political predicament influenced history education, but history education also served to perpetuate the political status quo: the insistence on ethnic difference, the lackluster efforts at reconciliation, the victimization of one's group and the lack of acknowledgment of the suffering of others.

Aside from ethnicization of education, the way in which Bosnia memorializes its past is also profoundly ethnically driven, serving a specific political purpose for each of the three major groups. For Bosnian Serbs, the past is remembered in museums, memorial sites, and contemporary books in a way that justifies claims to a separate political entity in Republika Srpska. For Croatians, memorialization efforts are used to emphasize the Croatianization of the Bosnian space, the affinity with Croatia as the principal homeland, and the unique Catholic character of the Bosnian Croatian ethnic group (Torsti, 2004). For Bosniacs, the past is put to use to justify political projects of unitary, majority-Bosniac Bosnia, a state built on the memory of great injustice, victimization, suffering and genocide (Plant, 2012).

It is this particular narrative of Bosnia as a state victim of genocide that Bosniac political elites have tried so hard to maintain. The power of the narrative has been evident, for example, in another project aimed at memorializing Bosnia's past: the comprehensive database of Bosnian wartime losses, also known as the Bosnian Book of the Dead. This massive database project carried out over many years by the Bosnian non-governmental organization, Research and Documentation Center, was meant to provide a narrative about every Bosnian victim, including known biographical information, family relations, as well as the circumstances of their death. When the project was 
completed in 2007, it provided evidence of close to 100,000 deaths, which, while still an incredibly high number, was much lower than the number of 200-250,000 deaths that has been circulating in the media for much of the past decade. $^{7}$

Instead of providing a sense of relief, even solace, that many fewer people have perished in the war, the findings of the project released a firestorm of hostility in Bosnia, including death-threats against the project director (Nettelfield, 2010b). The main problem with the project was that the revised death toll figures conflicted with the predominant narratives of victimhood and the character of the Bosnian conflict, a narrative in which Bosniac elites have a strong stake. The curious fact, however, is that international courts have already settled the issue of genocide that was committed in Bosnia-first in ICTY vs. Krstić and then in the Bosnia vs. Serbia genocide claim before the ICJ. Both of these cases provided convincing evidence that Bosnian Serbs, with Serbian support, had intended to destroy, at least in part, an ethnic group solely because of who they were, which is a definition of genocide. In fact, the Bosnian Book of the Dead provided even more hard evidence for the Bosniac claim that the war was predominantly an anti-Bosniac endeavor, as the final ethnic breakdown of civilian victims, $83 \%$ Bosniac, $10 \%$ Serb, and $5 \%$ Croat, showed clearly the majority of the victims. ${ }^{8}$ In the light of this breakdown, how many total victims the war produced is much less significant, which makes the backlash against the project that much more bizarre. This behavior only makes political sense if the Bosniac political elite insisted on maintaining the inflated death toll numbers in order to argue for a unitary Bosnia and to delegitimize Republika Srpska as a genocidal creation (Nettelfield, 2010b). The memory of the past, again, is being used to advance the political needs of the present.

\section{Existing Efforts-RECOM and Textbook Reform}

While official public space for reconciliation and justice projects has been constrained, civil society groups throughout the region have remained active and have put forward a series of proposals to deal with legacies of violence. Among many projects that have been initiated since the end of the conflict, two merit special attention: the RECOM commission initiative, and the regional history textbook project.

The initiative for RECOM (Regional Commission Tasked with Establishing the Facts about All Victims of War Crimes and Other Serious Human Rights Violations Committed on the Territory of the Former Yugoslavia in the period from 1991-2001) was launched in 2004. ${ }^{9}$ Today it brings together a network of more than 1800 nongovernmental organizations (NGOs), associations, and individuals who represent and promote the effort to establish a lasting regional commission. RECOM is not the first attempt to create a truth/ research commission to investigate the violence of the 1990s. Serbia in fact had a short-lived truth commission in the early 2000 s, but this institution was 
quickly co-opted by the government, and closed without issuing any report or obtaining any witness testimonies. A few NGOs in Bosnia also attempted to create a truth commission there, but this initiative did not have broad support either (Subotić, 2009).

What makes RECOM different is the regional, not state-centered, aspect of the project, as well as its origins in the civil society sector in Serbia, Croatia, and Bosnia. The RECOM project is also different from current mechanisms of transitional justice in the region, both international and domestic trials, in its emphasis on fostering public debate and sharing testimonies about the past, but not on individual prosecution (Jeffrey \& Jakala, 2012). Since 2004, RECOM has held dozens of conferences, multiple workshops and hearings around the region and collected half a million signatures demanding that states in the region officially recognize the Commission and put its recommendation into state practice. Herein lies the paradox of RECOM. While building on the strength of civil society activism and expertise in its multiple layers of addressing the injustice of the violent past, RECOM also must rely on state institutions in order to make its recommendations official and hence, truly meaningful and broadly transformative. RECOM has already been hampered by internal obstacles within the organizational structure of the broader human rights movement for which it is not equipped and should probably not supplant investigative prosecutorial efforts of the state (Kurze \& Vukusic, 2013). At the same time, what the region needs is change in public remembrance practices, education policies, and enforcement of transitional justice mechanisms, all changes that need to come from state agencies in order to be implemented (Irvine \& McMahon, 2013). Without official adoption of RECOM recommendations by regional governments, RECOM's worthwhile efforts will remain in the isolated sphere of civil society and human rights groups. They will remain aspirational, not operational.

Another regional initiative worth discussing briefly is the Joint History Project initiated by the Greece-based Centre for Democracy and Reconciliation in Southeast Europe (CDRSEE) in 2005. This broader regional initiative aimed to offer four alternative history textbook supplements to teachers throughout the Balkans, focusing on different perspectives on the historical experience of countries in the region, including the conflicting memories of war and violence. While also placing itself within the larger body of reconciliation efforts, this project did not aim for a uniformed, and mutually agreed upon, truth, but rather to the premise that historical disagreement and dissent, and management of differences, are a path to reconciliation (Johnson, 2012). While the textbook supplements were published and distributed, very few, if any, teachers in the region have adopted them. The obstacle to new textbook adoption primarily stems from the fact that textbook publishing and adoption remains heavily centralized and requires arduous bureaucratic approval by the ministries of education (Gasanabo, 2006). Being state agencies, education ministries are also reluctant to approve texts which are radically different in tone, language, narrative, and message than the ones that have been used for years. The state control of the textbook industry makes reform incredibly 
hard to initiate and maintain. History teachers, therefore, see no clear benefit to adopting textbook supplements that are not sanctioned or approved by the state and would, presumably, require them to do more work than if they only relied on official textbook materials.

\section{Conclusion}

This essay provided snapshots of contemporary state practices of remembrance in Serbia, Croatia, and Bosnia, and it makes an argument as to why these conflicting identities continue to be barriers to building a sustainable justice framework in the Western Balkans. The ways in which states remember their pasts are mutually exclusive. Serbian remembrance is built on the sense of Serbian victimization by Croats and Bosniacs, Croatian remembrance on liberation from Serbian aggression, and Bosniac remembrance on being survivors of the Serbian genocide. These histories cannot possibly all be true in their totality; parts of them are true, others exaggerated, yet others neglected. The region also faces a unique challenge in that victims and perpetrators no longer live with one another in the same state, a consequence of Yugoslav partition which has made domestic calls for justice much more difficult to push through official state channels. A related problem is that, in the Western Balkans, values continue to be defined on an ethnic basis; ethnic identity is still the ordering principle of political life, as is witnessed in the efforts at education remembrance and memorialization projects. The past in the Western Balkans has an ethnicity of its own.

This pessimism, however, does not mean that nothing should be done. Quite the opposite, much needs to be done. There are multiple available mechanisms of dealing with the past that have yet to be systematically implemented in the region. In addition to retributive justice and individual war crimes trials, models of reparative justice (such as state apologies or restitution to victims) have not even been considered seriously. The Bosnian genocide claim submitted to the ICJ was denied and those opportunities for reparations to victims and official state apology from Serbia have been squandered. However, a preferable mechanism would be for the state implicated in mass crimes to issue apologies or provide reparations on its own prompting, without the tools of international law. This would hold for Serbia and its crimes against Croatia and Bosnia, and for Croatia and its crimes against Bosnia. This idea may not be far-fetched. Willing to engage state responsibility for past violence can be useful for new governments politically, as they can use it to signal, both domestically and abroad, a profound break with the past. Serbia and Croatia should also offer to pay either reparations to victims individually or through generous community gifts (roads, schools, parks, memorial sites). While the prospects for this kind of profound political change are not immediately favorable, there have been some important gestures in this direction, mostly from Croatian president Josipović. The Croatian President has been, for the regions's standards, at 
least, unusually open and reconciliatory in his invitations for non-Croat refugees to return to Croatia, open to pushing for inter-ethnic dialogue, and openly directly apologizing on behalf of the Croatian state for crimes commmited against non-Croat civilians during the war (Banjeglav, 2013). He has also tied Croatia's reconciliatory behavior to its European ambitions, arguing that if Croatia is to join the European Union as a liberal democracy, it should act like one, especially in the area of human rights (Pavelić, 2012b). It is possible to imagine a similar set of circumstances developing in Serbia and Bosnia, if political leaders face significant and sustained international incentives for domestic political change.

Further, all three states should accept an official regional commission of inquiry into past atrocities, as well as commit to broadly disseminating the results of the commission and implement its recommendations into state policy. The ongoing RECOM initiative has that potential but it will not accomplish enough without official recognition by regional governments, a key piece that is still missing. ${ }^{10}$

Finally, all three states should implement comprehensive education reform, which includes textbook and curriculum reform that clearly presents evidence of crimes committed, the nature of the conflict, and the political environment that made the atrocities possible and even popular among wide segments of society. They should promote media professionalization, specialization, and education in the field of transitional justice- how to investigate war crimes, how to write about them, how to present evidence, how to protect the victims. The states in the region, and this is especially important for Serbia and Croatia, should also create national days of memory for victims of atrocities their own troops have committed, and set up museums or other types of memorial sites to remember victims and survivors. Continuing efforts by human rights groups are important, but so are maintaining the interest of the media and, above all, the will of major political actors. This is not something that can develop overnight, but it is a social transformation that can be motivated by external incentives (such as, for example, requirements of European Union membership), or by subtle mechanisms of international socialization and persuasion. This kind of slow transformation is already underway in Croatia and there is no reason to foreclose on the possibilities of similar developments elsewhere in the region.

These memorialization efforts are important in their own right, but they are a necessary component of a comprehensive post-conflict justice framework. The states of the Western Balkans are far from creating sustainable justice architecture, but revisiting how they remember their pasts is a key starting point. And some political leaders in the region seem to understand that more than others. At the most recent August 5, 2012 celebration of the Homeland War, Croatian president Ivo Josipović made significant steps in this effort when he said, "Croatia won the war, it is a great achievement . . . but Croatia still has to battle to win in peace. Winning in peace means also extending a hand to our Serb citizens, acknowledging and bowing to their victims" (Agence France-Press, August 2, 2012). It is a simple message, an elegant 
message, and it should be the start.

\section{Notes}

1 I should like to thank Diane Enns, Nataša Govedarica, Dana Johnson, Fernando Reati, and two anonymous reviewers for very helpful comments and suggestions.

2 Some of the material covering history textbook debates in Serbia and Croatia is adapted from Subotić, 2013).

3 The days in question commemorate Serbian victims of the battle against the Turks in 1809; Serbian losses in WWI and WWII, including at the Greek front in 1918, from German air attacks in 1941, and from Nazi genocide; and Serbian victims of the NATO air war in 1999

4 The city of Belgrade alone has renamed 1,500 or about one fifth of its street names since the early $1990 \mathrm{~s}$.

5 The Ustasha movement was a Croatian armed militia which, inspired by German and especially Italian fascists, ran Croatia in the 1940s as a puppet Nazi state. The Ustasha were responsible for mass atrocities against hundreds of thousands of Jews, Serbs, Roma and other "undesirable" [sic] non-Croat populations during World War II.

6 The number of victims at Jasenovac varies fantastically from the minimal number offered by Croatian nationalists $(40,000)$ to the vastly exaggerated number circulated by Serbian nationalists $(700,000)$. Most comprehensive scholarly analyses put the probable number at somewhere between 70,000 and 100,000 killed (Graovac \& Cvetković, 2005).

7 The research findings have since been published in Tokača, 2013.

8 Data from Tokača, 2013.

9 Detailed information about RECOM is available at the Organization's website portal http://www.zarekom.org.

10 An encouraging recent development, however, has been the official interest in the project by Croatian president Ivo Josipović and Montenegrin president Filip Vujanović (Zadarski list, August 15, 2012).

\section{References}

Agičić, D. (2011). Prikaz postanka suvremene Republike Hrvatske u hrvatskim udžbenicima [The Representation of the creation of modern republic of Croatia in Croatian textbooks]. In T. Cipek (Ed.), Kultura sjećanja: 1991. - Povijesni lomovi i svladavanje prošlosti [Culture of Memory: 1991 - Historical Clashes and Overcoming the Past]. Zagreb: Disput.

Agičić, D., \& Najbar-Agičić, M. (2007). History teaching in 1990s Croatia. In S. P. Ramet \& D. Matić (Eds.), Democratic transition in Croatia: Value transformation, education \& media. College Station: Texas A\&M University Press.

Aguilar, P. (2002). Memory and amnesia: The role of the Spanish Civil War in the transition to democracy. Oxford: Berghahn Books.

B92. (2012, 1 June). Izetbegović: Nikolić vređa Bošnjake [Izetbegović: Nikolić is Insulting the Bosniacs], from http://www.b92.net/info/vesti/index.php?yyyy=2012\&mm=06\&dd=01\&nav_ category=11\&nav_id $=614859$

Banjeglav, T. (2012). Sjećanje na rat ili rat sjećanja? [Memory of war or war of memories?]. In T. Banjeglav, N. Govedarica \& D. Karačić (Eds.), Re:vizija prošlosti: Politike sjećanja u Bosni i Hercegovini, Hrvatskoj i Srbiji od 1990. godine [Re:vision of the past: Memory politics in Bosnia-Herzegovina, Croatia and Serbia since 1990]. Sarajevo: ACIPS.

Banjeglav, T. (2013). Dealing with the past in post-war Croatia: Perceptions, problems, and perspectives. In O. Simić \& Z. Volčić (Eds.), Transitional Justice and Civil Society in the Balkans. New York: Springer.

Bell, C. (2009). Transitional justice, interdisciplinarity and the state of the "field," or "non-field". International Journal of Transitional Justice, 3(1), 5-27. 
Buruma, I. (1994). The wages of guilt: Memories of war in Germany and Japan. New York: Farrar, Straus, Giroux.

Byford, J. (2007). When I say "The Holocaust," I mean "Jasenovac". East European Jewish Affairs, 37(1), 51-74.

Cohen, S. (2001). States of Denial: Knowing about atrocities and suffering. Cambridge, Eng.: Polity.

Cole, E. A. (2007). Transitional justice and the reform of history education. International Journal of Transitional Justice, 1(1), 115-137.

Croatian Parliament. (2000). Deklaracija o domovinskom ratu [Declaration on the homeland war]. Zagreb. Narodne novine 102/2000.

Croatian Parliament. (2006). Deklaracija o Oluji [Declaration on operation storm]. Zagreb. Narodne novine 76-2000.

Ćurgus Kazimir, V. (2005). Zavera stida [Conspiracy of Shame]. In S. Biserko (Ed.), Srebrenica: Od poricanja do priznanja [Srebrenica: From Denial to Acknowledgment]. Belgrade: Helsinki Committee for Human Rights in Serbia.

David, L. (2012). A difficult past in Serbia: The state-sponsored project of remembering and forgetting. Paper presented at the Association for the Study of Nationalities World Convention, New York, NY, April 19-21.

Dimitrijević, N. (2008). Serbia after the criminal past: What went wrong and what should be done. International Journal of Transitional Justice, 2(1), 5-22.

Gasanabo, J.-D. n. (2006). Fostering peaceful co-existence through analysis and revision of history curricula and textbooks in Southeast Europe: Preliminary stocktaking report. Paris: UNESCO.

Goldstone, R. J. (1995). Justice as a tool for peace-making: Truth commissions and international criminal tribunals. New York University Journal of International Law and Politics, 28, 485503.

Govedarica, N. (2012). Zemlja nesigurne prošlosti [The state of insecure past]. In T. Banjeglav, N. Govedarica \& D. Karačić (Eds.), Re:vizija prošlosti: Politike sjećanja u Bosni $i$ Hercegovini, Hrvatskoj i Srbiji od 1990. godine [Re:vision of the past: Memory politics in Bosnia-Herzegovina, Croatia and Serbia since 1990]. Sarajevo: ACIPS.

Graovac, I., \& Cvetković, D. (2005). Ljudski gubici Hrvatske 1941.-1945. godine: pitanja, primjeri, rezultati [Human losses in croatia 1941-1945: Questions, examples, findings]. Zagreb: Zajednica istraživača dijalog.

Hayner, P. B. (1994). Fifteen truth commissions - 1974 to 1994: A Comparative Study. Human Rights Quarterly, 16, 597-655.

Hein, L. E., \& Selden, M. (2000). Censoring History: Citizenship and Memory in Japan, Germany, and the United States. Armonk, N.Y.: M.E. Sharpe.

Helsinki Committee for Human Rights in Serbia. (2011). Human Rights Reflect Institutional Impotence. Belgrade: HCHRS.

Hromadžić, A. (2008). Discourses of integration and practices of reunification at the Mostar Gymnasium, Bosnia and Herzegovina. Comparative Education Review, 52(4), 541-563.

Ignatieff, M. (1998). The warrior's honor: Ethnic war and the modern conscience. New York: Metropolitan Books.

International Criminal Tribunal for the Former Yugoslavia. (2012). Appeals Judgement in Prosecutor vs. Ante Gotovina and Mladen Markač. The Hague: ICTY.

Irvine, J. A., \& McMahon, P. C. (2013). From international courts to grassroots organizing: Obstacles to transitional justice in the Balkans. In O. Simić \& Z. Volčič (Eds.), Transitional Justice and Civil Society in the Balkans. New York: Springer.

Jeffrey, A., \& Jakala, M. (2012). Beyond trial justice in the former Yugoslavia. The Geographical Journal, 178(4), 290-295.

Johnson, D. N. (2012). Rewriting the Balkans: Memory, historiography, and the making of a European citizenry. MA Thesis, University of Massachusetts, Amherst.

Jones, B. (2012). Exploring the politics of reconciliation through education reform: The case of Brčko district, Bosnia and Herzegovina. International Journal of Transitional Justice, 6(1), 126-148.

Kolsto, P. (2010). Bleiburg: The Creation of a national martyrology. Europe-Asia Studies, 62(7), 1153-1174.

Kurze, A., \& Vukusic, I. (2013). Afraid to cry wolf: Human rights activists' struggle of 
transnational accountability efforts in the Balkans. In O. Simić \& Z. Volčič (Eds.), Transitional Justice and Civil Society in the Balkans. New York: Springer.

Manojlović Pintar, O. (2010). Rat i nemir [Peace and Uncertainty]. In D. Stojanović, R. Vučetić, S. Petrović Todosijević, O. Manojlović Pintar \& R. Radić (Eds.), Novosti iz prošlosti: Znanje, neznanje, upotreba i zloupotreba istorije [News from the Past: Knowledge, Ignorance, Use and Misuse of HIstory]. Belgrade: Belgrade Center for Human Rights.

McGrattan, C. (2010). Northern Ireland, 1968-2008: The politics of entrenchment. Basingstoke: Palgrave Macmillan.

McMahon, P. C., \& Western, J. (2009, August 17). The death of Dayton. Foreign Affairs.

Mendeloff, D. (2004). Truth-seeking, truth-telling, and postconflict peacebuilding: Curb the enthusiasm? International Studies Review, 6(3), 355-380.

Mendeloff, D. (2008). "Pernicious history" as a cause of national misperceptions. Cooperation and Conflict, 43(1), 31-56.

Minow, M. (1998). Between vengeance and forgiveness: Facing history after genocide and mass violence. Boston: Beacon Press.

Nettelfield, L. J. (2010a). Courting democracy in Bosnia and Herzegovina: The Hague Tribunal's impact in a postwar state. New York: Cambridge University Press.

Nettelfield, L. J. (2010b). Research and repercussions of death tolls. In P. Andreas \& K. M. Greenhill (Eds.), Sex, drugs, and body counts: The politics of numbers in global crime and conflict. Ithaca: Cornell University Press.

Oglesby, E. (2007). Educating citizens in postwar Guatemala: Historical memory, genocide, and the culture of peace. Radical History Review, 2007(97), 77-98.

Orentlicher, D. F. (2008). Shrinking the space for denial: The Impact of the ICTY in Serbia. New York: Open Society Institute.

Orentlicher, D. F. (2010). That someone guilty be punished: The Impact of the ICTY in Bosnia. New York: Open Society Justice Initiative and International Center for Transitional Justice.

Pavasović Trošt, T. (2012). Dealing with the past: Identity narratives among Serbian and Croatian Youth. PhD Dissertation, Harvard University, Cambridge, MA.

Pavelić, B. (2012a). Croatia and Nikolic: Shock mixed with irony. Balkan Insight. 28 May. Retrieved from http://www.balkaninsight.com/en/article/croatia-shock-and-irony-aboutnikolic

Pavelić, B. (2012b). Croatian president wants serb refugees to return. Balkan Insight. 8 October. Retrieved from http://www.balkaninsight.com/en/article/josipovic-croatia-wantsserbs-to-return

Pavlaković, V. (2008). Red stars, black shirts: Symbols, commemorations, and contested histories of World War Two in Croatia. Seattle: The National Council for Eurasian and East European Research.

Pavlaković, V. (2010). Croatia, the International Criminal Tribunal for the former Yugoslavia, and General Gotovina as a Political Symbol. Europe-Asia Studies, 62(10), 1707-1740.

Perry, V. (2013). Classrooms as a battleground for hearts and minds: efforts to reform and transform education in post-war Bosnia and Herzegovina. In O. Listhaug \& S. P. Ramet (Eds.), Civic and Uncivic Values in Bosnia-Herzegovina: The Record Since Dayton. Ravenna: Longo Editore.

Plant, E. (2012). The politicisation of victimhood. Paper presented at the SIT Symposium "Conflict, Memory, and Reconciliation: Bridging Past, Present, and Future", Kigali, Rwanda, January $10-13$.

Ramet, S. P. (2007). The denial syndrome and its consequences: Serbian Political Culture since 2000. Communist and Post-Communist Studies, 40(1), 41-58.

Sarkin, J. (1999). The necessity and challenges of establishing a truth and reconciliation commission in Rwanda. Human Rights Quarterly, 21, 767-823.

Stojanović, D. (2011). An explosive device with a delayed effect: Image of the wars of the nineties in Serbian history textbooks (1993-2005). In T. Cipek (Ed.), Kultura sjećanja: 1991. - Povijesni lomovi i svladavanje prošlosti [Culture of Memory: 1991 - Historical Clashes and Overcoming the Past]. Zagreb: Disput.

Subotić, J. (2009). Hijacked justice: Dealing with the past in the Balkans. Ithaca: Cornell University Press.

Subotić, J. (2013). Stories states tell: Identity, narrative, and human rights in the Balkans. Slavic Review, 72(2), 306-326. 
Teitel, R. (2003). Transitional justice genealogy. Harvard Human Rights Journal, 16, 69-94. Tokača, M. (2013). Bosnian book of the dead. Sarajevo: Research Documentation Center. Torsti, P. (2003). Divergent stories, convergent attitudes: Study on the presence of history, history textbooks, and the thinking of youth in post-war Bosnia and Herzegovina. PhD Dissertation, University of Helsinki, Helsinki.

Torsti, P. (2004). History culture and banal nationalism in post-war Bosnia. South East European Politics, 5(2-3).

Torsti, P. (2013). Rival histories \& textbook reform in bosnian textbooks 1992-2009. In O. Listhaug \& S. P. Ramet (Eds.), Civic and Uncivic Values in Bosnia-Herzegovina: The Record Since Dayton. Ravenna: Longo Editore.

United States Institute of Peace. (1993). Report of the Chilean National Commission on Truth and Reconciliation. Washington, DC: USIP.

Weinstein, H. M., Freedman, S. W., \& Hughson, H. (2007). School voices: Challenges facing education wystems after identity-based conflicts. Education, Citizenship and Social Justice, 2(1), 41-71. 